Final Synthesis

BEYOND_WORDS: MAKING MEANING OF TRANSITIONING TO MOTHERHOOD USING MONTAGE PORTRAITURE

A play in four acts 


\section{Cast of Characters}

Sitters:

Margaret

A woman in her $30 \mathrm{~s}$

Gabriela

A woman in her $30 \mathrm{~s}$

Liz

A woman in her $30 \mathrm{~s}$

Taylor

A woman in her $30 \mathrm{~s}$

Alex

A woman in her $30 \mathrm{~s}$

Portraitist:

Victoria

A woman in her $30 \mathrm{~s}$

The artist's studio.

\section{Time}

The present. 


\section{ACT I \\ Scene1}

SETTING: We are at an artist's studio. Warm, reduced lighting. A room with 5 chairs for the sitters. A chair for the portraitist. A table to work on for the portraitist. Art materials: pens, ink, pencils, brushes, water color, and collage materials on the artist's desk. A large screen behind the actresses where the artwork is being projected.

AT RISE The portraitist is moving around the studio, organizing the art materials.

VICTORIA

(organizing the studio, moving the materials around, looking at the watch. Pensive).

Ok, almost ready... this is the final synthesis of my arts-based dissertation research. 5 first-time mothers have agreed to come and sit for a group portrait. I have already met each of them individually. They have used self portraiture and oral reflections to express their beyond words experiences about transitioning to motherhood. Based on these data, I created individual portraits of each of them that they saw and provided feedback on. Some of the mothers were really curious to meet the other participants, and so I think that this group portrait is a great opportunity for them to come together and for me to synthesize the results from this study.

(knock on the door).

Come in!

VICTORIA

(Enter: MARGARET, LIZ, GABRIELA, TAYLOR, ALEX)

VICTORIA

Hi! Great to see you, thanks for coming. Take a seat, please. How are you?

(all sit) 
MARGARET, LIZ, GABRIELA, ALEX, AND TAYLOR

Great! Excited! I'm doing well. Good to see you again.

VICTORIA

I'm so glad that you all got to come and meet each other.

MARGARET, LIZ, GABRIELA, ALEX, AND TAYLOR

(Animated) Yeah! Me, too! This is exciting.

VICTORIA

Thank you so much for agreeing to sit for the group portrait. This is the first time that you all get to meet each other and I'm very glad to see you all. Let me explain the purpose of this group portrait.

As you know, I am an art therapist, artist and arts-based researcher, and I am using my skills to study first time mothers' experiences of becoming mothers. I am particularly interested in what I call beyond_words experiences. I would like to know what sensations you have when you touch or hold your baby, your thoughts, or the emotions your feel in your transition to motherhood. You may even have dreams, memories, and fantasies about adjusting to motherhood. I call these sensations and emotions beyond_words, and I know that they are difficult to put into words.

Sometimes similes and metaphors can help articulate what's beyond_words. Therefore, it would be great if while I'm working on the group portrait, you could informally talk amongst yourselves and use metaphors to describe your experiences, and I will try to capture what emerges.

Since you all have babies to attend to, I would like to ask you to sit for three short sessions instead of one long one, and you can provide feedback at the end. I wonder if you have any questions.

LIZ

I have a question. So, can you explain, is what we are going to be doing now art therapy?

VICTORIA

That's a great question! It may look like art therapy because you will expressing and sharing your experiences, however it is different from art therapy in that today you will not be creating art, and what you are sharing today is going to be part of the final synthesis of the arts-based research study. Last 
time we met you created artwork as data generation but today, I will be combining my skills of an artist and arts-based researcher to use what you all contribute to this group to create the final synthesis of results which is going to be a group portrait.

LIZ

Oh, ok, thanks, that clarifies my question!

ALEX

I wonder, if your purpose is to represent first time-mothers experience, and this is a research context, what happens if we disagree on something?

VICTORIA

Thanks for asking this question. This is an arts-based research study and so the purpose of this is not to generalize the results but communicate the multiplicity of experience to the audience. Based on what I've gathered in our previous meetings, I know that there are topics that you all have in common but it doesn't really matter if you agree with each other. Each of you has rich and unique experiences and I will try to represent them.

\section{GABRIELA}

What about confidentiality? I want to share my portrait and my story but I don't want people to recognize me.

\section{VICTORIA}

That's totally understandable! You will not be recognized because I will use my skills as an artist to change your facial features, hair, eyes, etc. I will create a character that represents your experience but does not look like you.

\section{MARGARET}

(Hesitant) I wonder if we could get started...?

\section{VICTORIA}

(laughing) Yes, of course. If there are no more questions for now, we can get started and please feel free to ask any questions during our work together. I really see this group portrait as a co-creation. I will be working on the final portrait but the material for the portrait emerges between all of us during our time together. I wonder if you could start by briefly introducing yourselves to each other. Perhaps you could say your name, your baby's name and age, perhaps your own age... 
(Energetic) Ok, I can start. I am Liz, I'm 33 years old, and my baby boy Blue is 4 months old. Thanks for inviting me to sit for this portrait. This is just an amazing idea!

TAYLOR

(Calm, contained) Hi! My name is Taylor, I am 33 years old, and I have a baby boy Carter who is 8 weeks old.

I have been adjusting to the daily challenges of motherhood. This opportunity to come together with other moms for a group portrait is quite fascinating and I'm interested in participating.
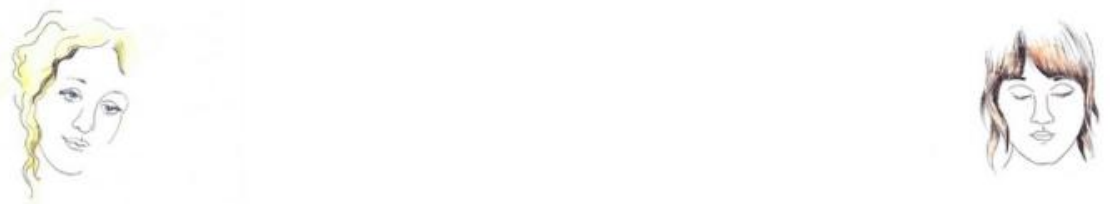

\section{ALEX}

I'm Alex, I'm 35 years old, and my baby Ethan is 8 months old. I'm so curious about this project. I've been really wanting to give attention to processing how mothering has affected me so far, but I haven't found the time or an appropriate channel for it. 

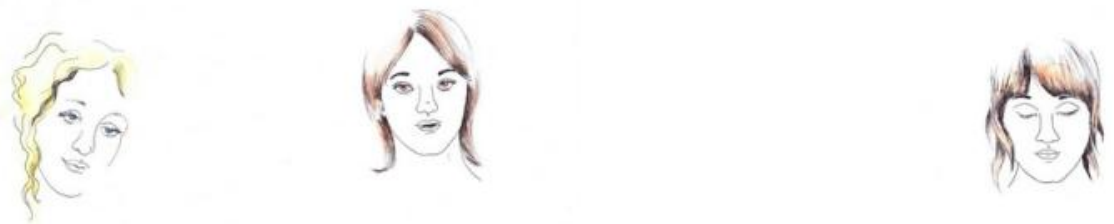

\section{MARGARET}

Hi! I'm Margaret, 31 years old, and I had baby Iris 4 weeks ago, so I'm really new to motherhood (smiling). A colleague of mine recommended that I should meet other new moms so I'm glad to meet you all.
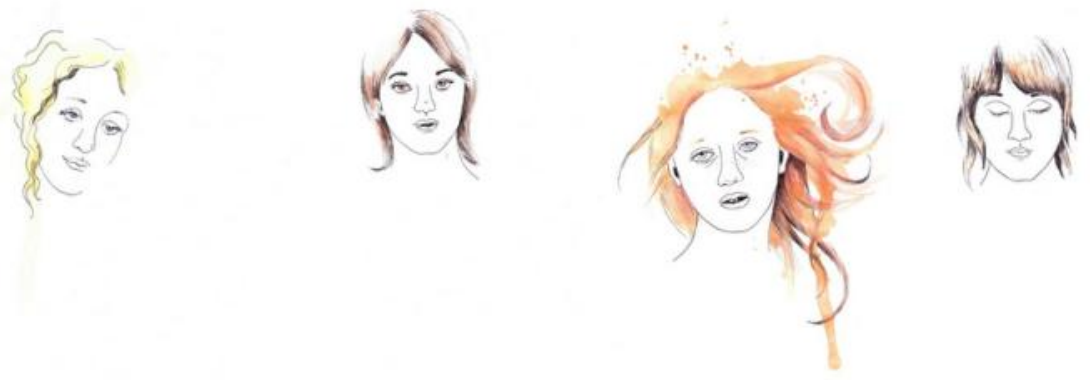

\section{GABRIELA}

Hi! I'm Gabriela, I'm 38 years old and my daughter Alison is 11 months old. It's great to meet all of you, and I look forward to our time together. 

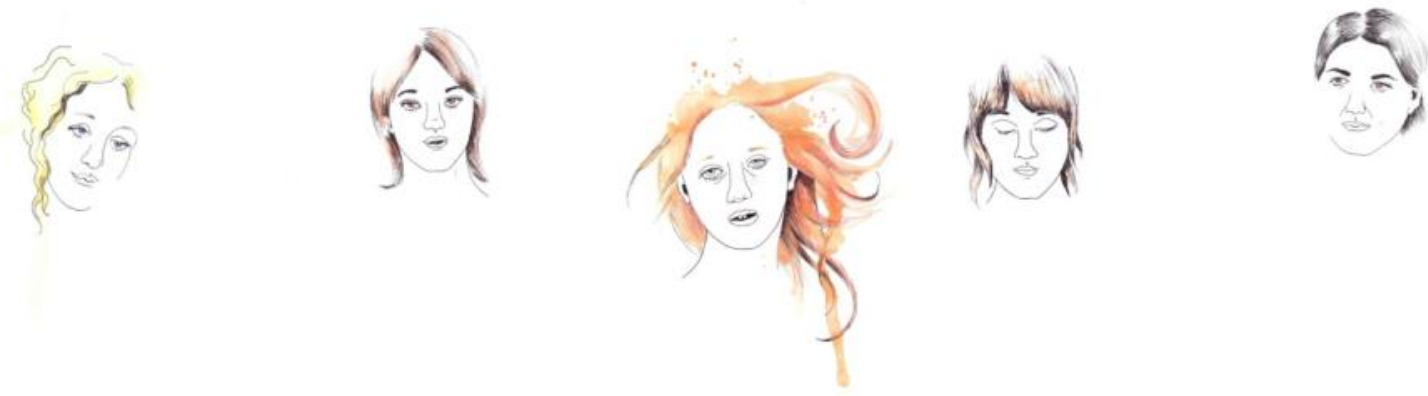

VICTORIA

Thank you all! To get started, please make yourselves comfortable, I am hoping to make it a really informal and friendly meeting. I will be sketching the portrait while you can chat, and let's see what we'll come up with. I wonder if we could get started by exploring the sensory-embodied experiences that you have experienced in transitioning to motherhood.

Scene2: Holding
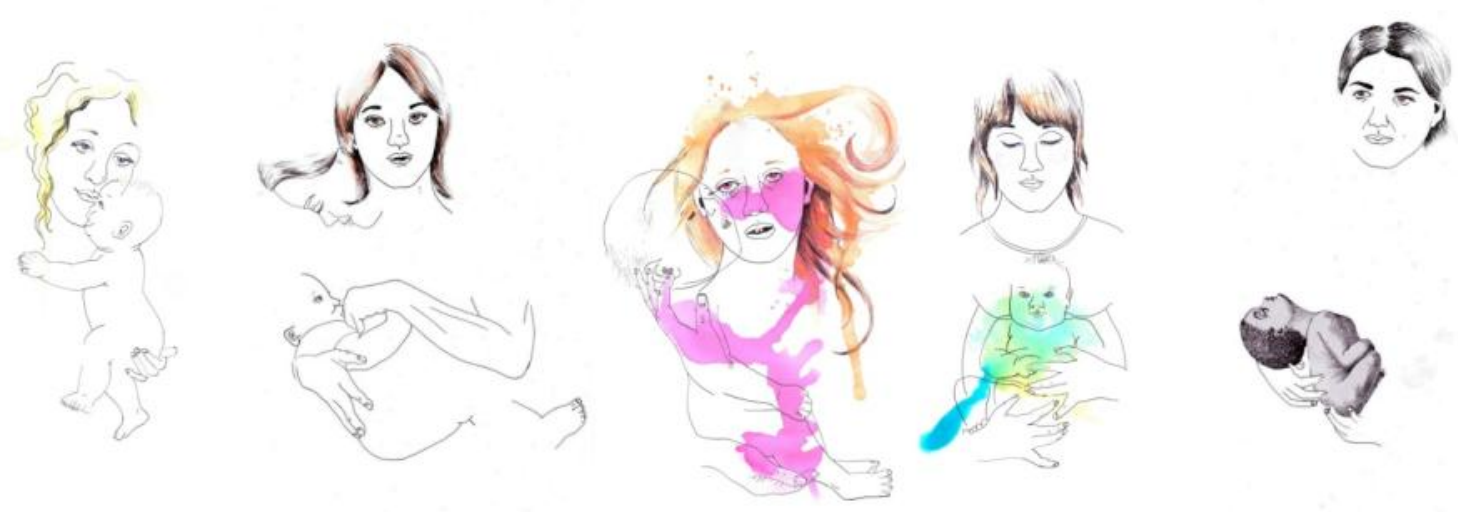

LIZ

(Softly, smiling) Yes, I definitely have these distinct experiences when I hold my baby. I always want to hold him, touch him, hold his little hand - it's totally addictive! The top of his head is so smooth and has a little bit of hair and it's so soft and I just want to rub my face all over it. When I pick him up and hold him, he feels soo0o good! Just the weight of his body, and the size of it and how warm it is and how he's little, there's something about holding him just like this that s just soooo good. 
MARGARET

I love holding Iris, putting my face next to hers... it's completely intoxicating! I get such a buzz from having her on me. What this brings up is warmth, the color pink. I would like to paint my face, and the insides of my eyes, pink.

LIZ

(Animated) Totally! It feels very distinctly chemical, I would also say it's intoxicating.

\section{TAYLOR}

Holding Carter makes me feel overcome with love... even when I am stressed out or tired, it just melts a little bit. Because it can be really wearisome...

\section{ALEX}

I hear you. Sometimes I also have stressful days at work but when I get home and pick him up, I just want to cuddle him, and ... and it's curious that the pain in my body does not prevent me from being any closer to him. It's fascinating how that closeness trumps all pain. Being close to him brings up sweet, gentle sensations.

\section{GABRIELA}

Yes, it's so nice to hold her! I remember when she was a newborn, she was so tiny and fragile, like an egg that I was afraid to break.

\section{Scene3: Protection}

\section{ALEX}

Yes, I just have a desire to protect him.

\section{MARGARET}

Me too! I keep her close to my body, even at night, and I feel that she's so safe, so protected next to me.

Scene4: Breastfeeding 

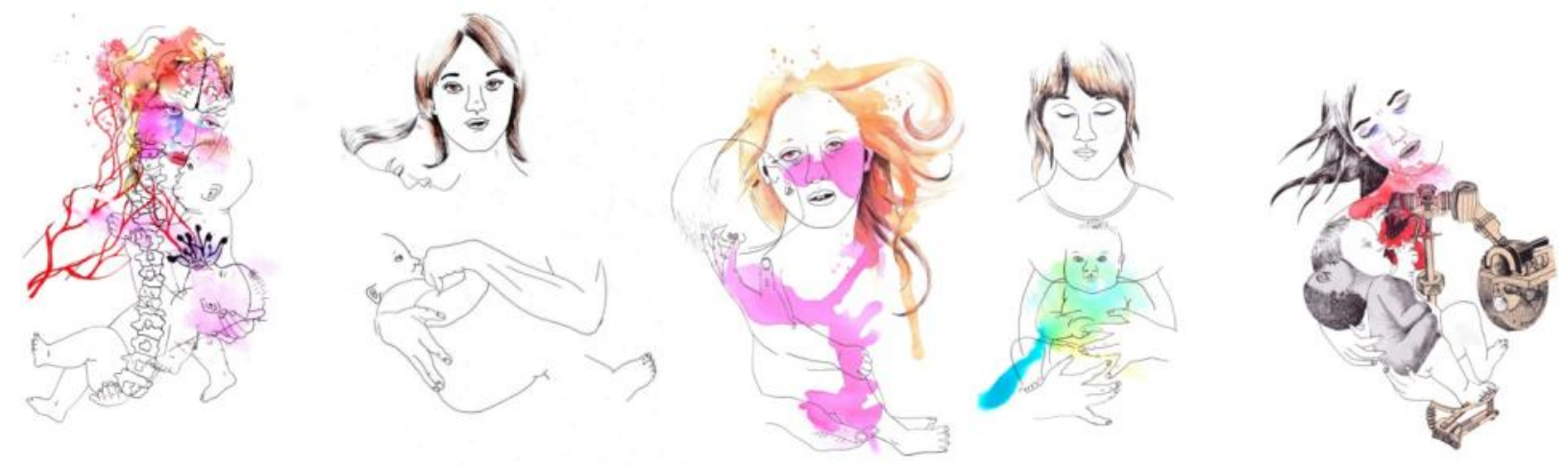

MARGARET

Speaking of which (sighs), I love being close to her but this bodily connection can also be challenging. My biggest challenge right now is breastfeeding. She nurses a lot, and it makes me pretty sore. You know, it's quite painful. I want to breastfeed and I am trying to figure it out. Any suggestions?

\section{LIZ}

(Animated) oh my god! You are not the only one. Figuring out how to breastfeed was MURDER for me. With tears in my eyes, I struggled with figuring out how to breastfeed. It was sooo frustrating!

You should talk to a lactation consultant who can give great advice and help with breastfeeding because it's really worth it. After the initial difficulties, breastfeeding now is the best thing in the world. Like I said before, it's intoxicating, it's distinctly chemical, like morphine that moves up my spine, and through my blood stream,... and finally it hits my brain. I's like ooohhh! It feels soooo good! Now I don't dwell too much on these initial difficult experiences, I'm even starting to forget them. But my body still remembers, I guess...

\section{GABRIELA}

I went through the same thing. In the beginning, my whole life revolved around breastfeeding. My body became a feeding machine, I can almost envision the wheels and bolts and little mechanical parts to make milk every couple of hours. I was feeding and feeding and feeding... and I was exhausted but she thrived on being breastfed. Ever since she was a newborn, Alison had a great appetite, I always breastfed her and am still breastfeeding.

\section{LIZ}

Yes, they really thrive on breastfeeding, and eventually once you figure it out, you'll see how wonderful it is. His warm 
little body, and he just nestles into me. I usually breastfeed him in my lap and he just curls into me and he just closes his eyes and falls asleep and takes a little nap. Yeah, that's pretty glorious! But as I said, the beginning was hard.

GABRIELA

I agree with Liz, it definitely gets better with time. But for me, breastfeeding was one of the most difficult experiences. EVER. Now that I look back to the first months of breastfeeding, this time is all red and black for me. It's emotionally difficult and physically painful. But as I said, in the end it's worth it.

\section{ALEX}

(Looking over at the portrait). If I may interrupt, on a different note, Victoria, I was really struck by the portrait that you created of me. I just can't help sharing with you that I feel overwhelmed by it in a way. I am surprised that I had such a strong reaction to this but I feel that it is somehow preventing me from focusing and sharing my story further.

\section{VICTORIA}

I'd love to hear your thoughts. Go on!

\section{ALEX}

I simply can't wait to digest all of this but... there's something in the look and in the eyes. They look sad, distraught and distanced. I haven't even shared my story but... let's just say that of course, this experience of becoming a mother is really profound, full of all kinds of emotions: deep, powerful... But I have definitely been present, not absent as this portrait makes me feel.

\section{VICTORIA}

Hmmmmm... thanks for sharing this, Alex! I see this portrait as co-creation between you and me. I believe that thanks to your feedback and suggestion this really comes to life, and I'm very open, in fact, inspired, to revising the portrait. Is there anything in particular that you would like to change?

ALEX

I would change my eyes or mouth expression to reflect a bit more joy $\ldots$

VICTORIA

Thanks for these suggestions. I will be happy to revise the portrait, and you can tell me what you think. ok? 
ALEX

Wow, thank you! I had no idea you'd be willing to revise...

VICTORIA

Of course! I will keep working on the updated version and you'll let me know later what you think. Meanwhile, let's continue... we were talking about holding the baby, breastfeeding...

Scene 4: Connected as one organism
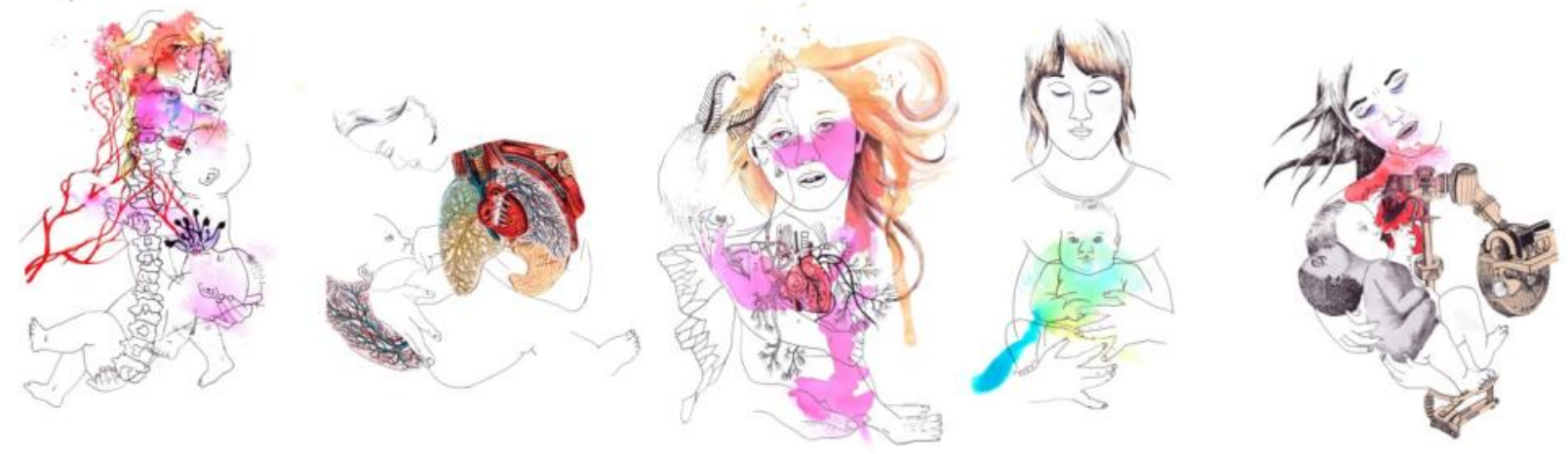

\section{MARGARET}

Yes, and related to that...The physical closeness also makes me feel connected to her, like one organism.

\section{LIZ}

Sometimes I also feel that he's just one of my organs that has escaped and is wandering around.

\section{ALEX}

And yes, we are one; he is such a part of me. My cells forever embedded in him, and his presence forever embedded in me.

\section{MARGARET}

Speaking of which, it's surprising to me how much a newborn seems like a little animal. She goes by instinct to get what she needs in order to thrive: searches for the nipple, cries... She reminds me of a little pig or a little bug, a little critter with feelers, something soft, like a little moth.

\section{GABRIELA}

(Laughing) Yes, they are just little animals trying to survive...

\section{LIZ}


Blue just figured out how to grab onto things and ... he reminds me of a little monkey. So cute! We are all monkeys, it's

wonderful.

\section{Scene 5: Pregnancy}

TAYLOR

I feel that this connection, this oneness began in pregnancy, so it's something really strong, this bodily connection. Like Alex said, we are one, my cells are embedded in him.

\section{GABRIELA}

Yes, that was beautifully said. As a scientist, I am just really fascinated how a baby develops from a cluster of cells. That's what Alison was in the beginning...

\section{TAYLOR}

It's weird, I've had sensations of still being pregnant with him...which brings up a dream related to pregnancy that I had recently, but I can't recall it now. Maybe it will come to me later...

\section{ALEX}

I've also had sensations related to pregnancy, the desire to be one with the baby. While practicing in the yoga studio this morning, I had this visceral, bodily experience. I was

practicing a powerful movement, bearing down all my weight to express connectedness to the earth, to myself. And then,... aaahh! a painful knot in my stomach followed by a vision of myself being a nutshell and Ethan being a nut inside of me. The nut was very embryotic and he felt so protected inside. Suddenly, I experienced a strong desire to have him inside of me again. And I envisioned us floating in the ocean...
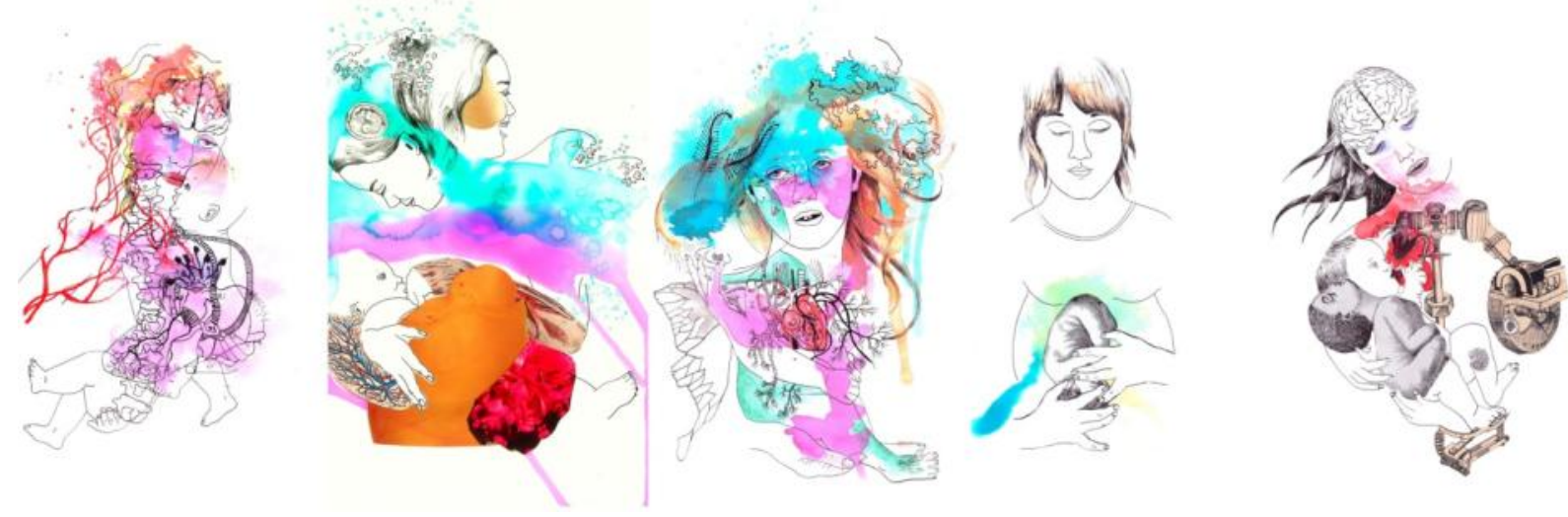
Scene 6: The baby is an ocean

\section{MARGARET}

There's something about the ocean, water... The other day I envisioned that Iris was like an ocean: she can be very tranquil but then she can become like crashing rolling waves that are pretty out of control.

And she encroaches on me this kind of wild energy, like an ocean wave rolling over my head.

(Pensive) It's like being in a totally new place that's completely under water, and learning how to breathe again, learning how my body works here. I am learning to adjust to this new reality...

\section{VICTORIA}

Wow, thank you all so much for this inspiring time together. I feel privileged to hear your stories, and really inspired to work on the portrait. Let's meet again next week, and continue where we left off today.

ALEX, GABRIELA, MARGARET, LIZ, TAYLOR

(Participants exiting) Thank you! See you next week! Thank you all! It was great meeting everybody.

\section{VICTORIA}

(Sitting on the chair, sighs. Then looks up at the portrait). This is the first draft of the portrait. I am not trying to copy their looks but to convey their experiences. To do so, I feel that capturing the emotion in their facial expressions are so important. Margaret's large eyes were wide open and she seemed to be in a state of wonder, she also had a very poetic and rich way of speaking...

My overall impression of Liz was a sense of serenity, meeting her was almost like a religious experience, her appearance and demeanor reminded me of a Renaissance Madonna.

Gabriela is almost at the end of her first year as a mother and it seems to me that she is looking back to it from some distance now... and also looking forward...

Taylor seems so calm, contained, introspective...

Alex struck me as... someone who is confident with herself. It was easy to make an emotional contact with her. The biggest impression, though, to me was her incredible connection with 
herself and her own body. her honesty is really impressive, and also the way that she challenged my representation of her. Now that I look at the portrait, I see what she means. My intention was to portray her strength and connectedness to herself and her baby but by focusing on that, perhaps I overshadowed the gentle person that she is. I am going to revise the portrait now and will show it to her next time.

\section{(exits)}

END OF ACT I 
ACT II: Relational experiences

Scene1: Introduction

SETTING: A week later at the artist's studio.

AT RISE: $\quad$ Portrait projected on the screen. Victoria is in the studio, working on the portrait.
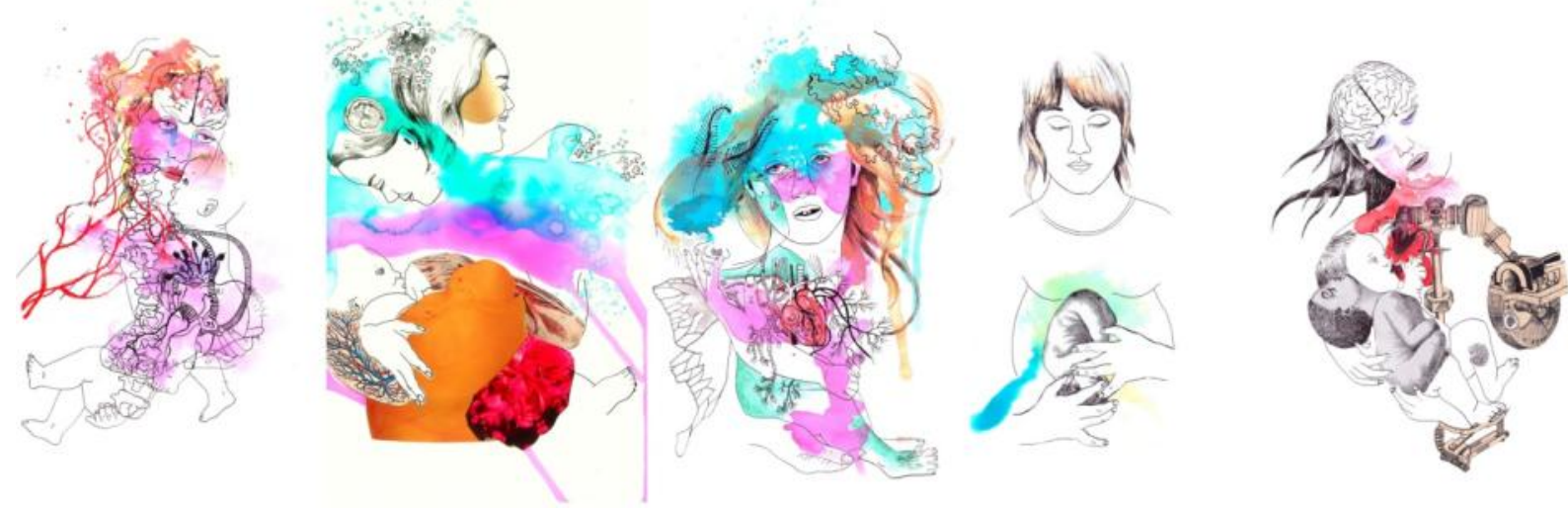

(enters Margaret)

MARGARET

Hi! How are you?

VICTORIA :

Hi! I'm well. Good to see you. How's everything?

MARGARET

I just wanted to tell you that I'm so glad to meet the other moms last week. I have so much to tell, to ask today... VICTORIA

That's great! Let's wait for the others, then. (another knock on the door)

Oh, here they are! Come in!

(enters Alex)

$\mathrm{Hi}$ !

ALEX

VICTORIA

Hi, Alex! I'm so excited to share with you the revised portrait. Would you like to take a look? 
Sure. Wow! This is so different! The changes are powerful, and I really like how it looks. This is much more representative. Thank you so much for revising!

VICTORIA

You are most welcome, it's my pleasure. And thank you for your suggestions and observations.

$\mathrm{Hi}$ !

$$
\begin{gathered}
\text { (enter Taylor, Liz, Gabriela) } \\
\text { TAYLOR, LIZ, GABRIELA }
\end{gathered}
$$

Hello! Hi! How are you?

$$
\text { VICTORIA, MARGARET, ALEX }
$$

VICTORIA

Shall we get started? Let's continue where we left off. Last time, we were talking about breastfeeding, physiological sensations... I wonder if today we could talk about relational experiences with the baby.

\section{Scene 2: Breastfeeding tied in with the relationship}
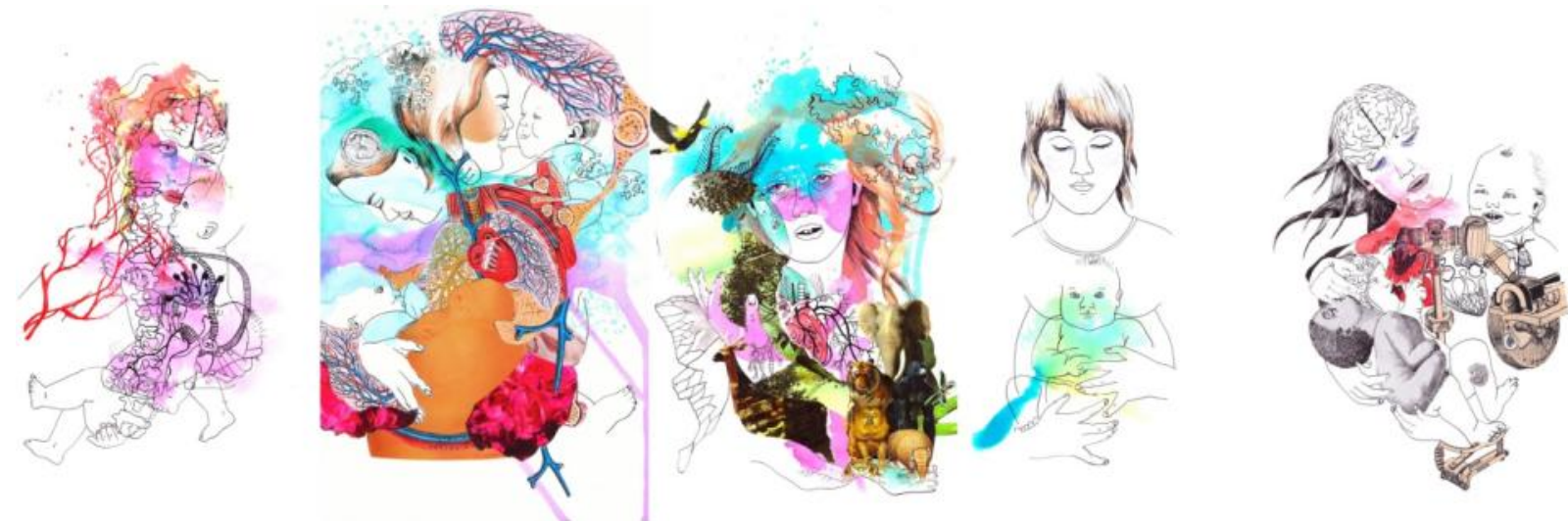

ALEX

Well, breastfeeding a huge topic that also carries over to speaking of relational experiences because for me, breastfeeding is such an important part of our relationship. It is one of the primary connections that he and I have that no one else has with him. So it is transformative for me as a mother, and it feels really special.

\section{LIZ}

I feel the same way, breastfeeding is such a huge part of our relationship, and I love it sooo much!

Scene 3: One-way relationship vs reciprocated relationship

GABRIELA 
Yes, definitely, breastfeeding is totally central in our relationship as well, both physiologically and emotionally. You know, my baby is almost a year old, and I'm still breastfeeding. But then again, breastfeeding is so central that I wonder is all she sees in me is a source of food? I think at first, yes, definitely, her brain was just wired for survival and the brain cells and instinctual processes were telling her what to do to get fed and get her needs met. Like we discussed yesterday, babies are just like little animals... but the relationship evolves and eventually she starts recognizing me as a person, not just a source of food. At first, it definitely was a one-way relationship. It's like a one-way love, I think.

\section{MARGARET}

I'm new to this, so I have some mixed and confused emotions about our relationship at this point. Iris is only 4 weeks old and she's not smiling yet so it's hard to feel like she's a loving grateful being. She feels like a strange cuddly... alien and it's my job to take care of her and love her and adore how fun and weird and funny she is but it doesn't feel like it's reciprocated ... yet. We are definitely connected but it's not a reciprocated relationship.

LIZ

Wow, I have heard other women speak of this. For instance I have a friend who is due in 3 weeks and is getting nervous about the upcoming delivery and attaching to the baby. She had read in a parenting magazine that for the first couple of months babies just take, they don't give anything back. I told her that for me, it is TOTALLY NOT TRUE! Like totally! He loves us sOOO much and gives lots back. Even as a little newborn ...he wasn't smiling like an older baby would do but he was a ball of attachment! I experience the contact with Blue emotionally and physically, and this relationship is so reciprocal, so satisfying, it's magical.

Scene 4: Connection with the baby

\footnotetext{
ALEX

I agree that the emotional part of our relationship is very satisfying and profound. I experience a strong connection with Ethan when we look at each other. I remember from early on, when he was looking into my eyes, it felt like he was looking into my SoUL and that he was going to know me differently than anyone ever will.
} 
Yes, when he started recognizing us, looking at us, oh my god, that was so magical! It's so nice!

ALEX

Yes, and when I look at him, I see myself in him, he reflects back to me like a mirror. I realize that he smiles because I smile, and he's serious because I'm serious, so he serves as a check and balance for me.

MARGARET

I can relate to that! I definitely feel this connection with Iris, I almost feel like I'm existing within her... we are intertwined like an ecosystem.

Scene5: Relationship evolves over time

GABRIELA

Well, and I think that the relationship also evolves over time. For me, at first it was a one-way love but as Alison got older, I felt more and more that there's this connection to her heart.

TAYLOR

Yes, definitely the relationship is constantly evolving. I can already see from the 8 weeks how it's changed, and can imagine how it's going to evolve even more. It's fascinating on the one hand, but on the other hand, it's also a challenge to constantly adjust and grow in this relationship...

Scene 6: Coping with stressors of adjustment

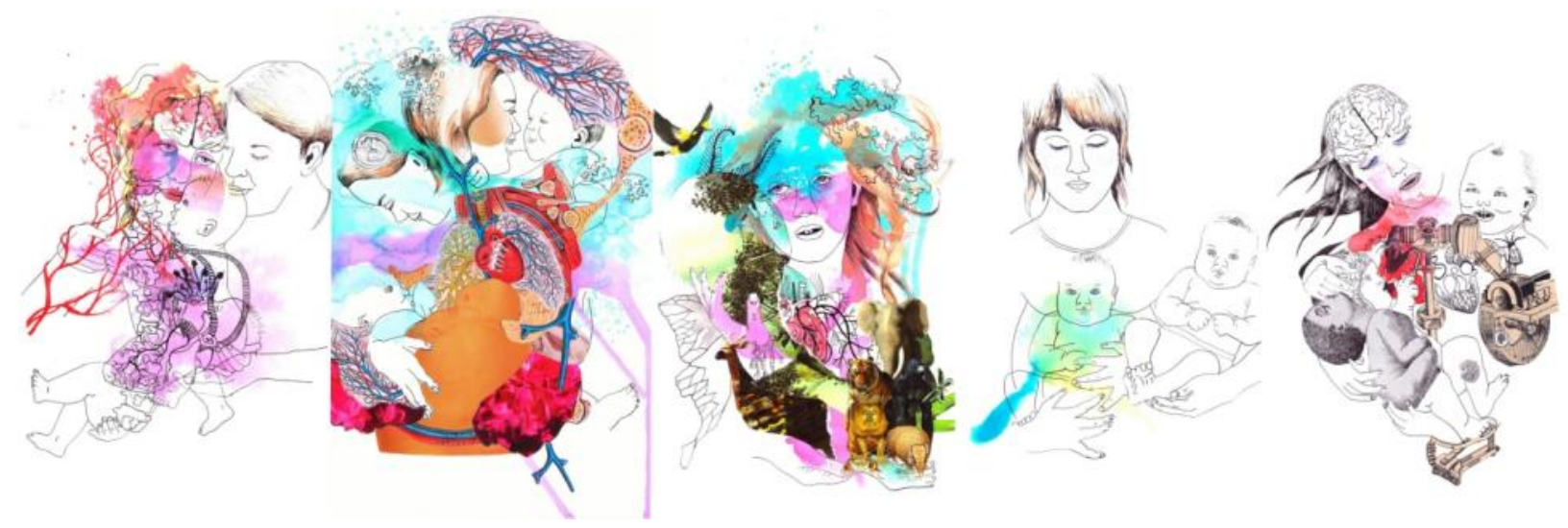




\section{VICTORIA}

Speaking of which, I wonder about adjustment to motherhood. You are all first-time mothers in different phases of your first year. How do you cope with the stressors of adjustment?

\section{MARGARET}

Thanks for bringing it up! I'm eager to hear about all of your experiences. It's been only 4 weeks since I delivered, and I feel that I need to organize myself. Right now, I feel that I'm surrounded by clutter, physically and metaphorically. Between the leaky breasts, and the baby pooping and producing all these diapers. On top of that, I have all these tasks to do: submitting disability paperwork, and writing thank you notes to people who have helped us out in some way...

LIZ

You know, it's a huge life change.

(everybody nodding)

\section{LIZ}

I kind of anticipated that everything would change but I didn't REALLY understand the magnitude of change...I can't pinpoint what exactly has changed, but EVERYTHING has changed! My experiences of everyday life, my friendships, attitudes, relationships, my work, everything! I used to be tidy and neat but now it's fine. I don't care. I could spend this time mopping the floor or play with the baby and I don't care about the floor, so...yeah!

\section{MARGARET}

This makes me feel better but still, there are things that have to be taken care of... and it feels like a lot.

\section{TAYLOR}

I hear you, it can get really overwhelming. Keeping things organized and contained is the key to successful coping! Like this morning when I wanted to straighten up the kitchen, and also shower and get myself ready, Carter started fussing. In order to get things done sometimes you need to tell the baby: "I need to take care of me so I can take care of you".

MARGARET

(Exhausted) I've had no time for myself, I am not getting any sleep... 
I think that what's most difficult to explain to people is that as a mom you also need some time for yourself.

\section{GABRIELA}

Yes, you need to take care of yourself but you are exhausted and not sleeping. I usually cope pretty well with adversity but this was one of the hardest times in my life. I felt drained, truly. Words cannot even begin to describe how tired I felt. But then again, at some point you don't complain about it either because ... it's just a part of it (sighs).

TAYLOR

I am fortunate I have a supportive family and a husband who help out with childcare. You should use all the support that you can get. I feel that I definitely need a bit of a breather at the end of the day when my husband comes home. Last night when Jerry came home from work, I just handed Carter to him and he took over so that I could just do what I needed to do.

\section{GABRIELA}

(laughing) But sometimes the family can also get a bit frustrating. Especially in the beginning when everyone wants to be there and tell you their opinion and what to do and what not to do. So it's really hard to explain to them that you are exhausted and trying to do your best... but yes, my husband has been a really big help and support.

\section{LIZ}

Mine, too! We share caregiving and he's been a tremendous help. By the way, Victoria, I know that my husband is not here but I wonder if you could somehow add him into this portrait... really can't imagine my portrait without him.

\section{GABRIELA}

Yes, I feel the same way! My husband has been tremendously helpful and supportive. Maybe you could just add my husband's arm around me, I feel that he should be represented somehow.

\section{VICTORIA}

Yes, definitely, let's see what I can do.

MARGARET

You know, my husband is also really supportive and helps with the baby but I get really anxious when the baby cries... 
LIZ

I know! I always find myself checking on the baby, like where is he? Is he ok?

TAYLOR

We try to keep the mood pretty light, and stressing out is not going to help anybody. And every day is different, so try to take one day at a time.

\section{GABRIELA}

I can tell you: it will get better! But it's hard work, and it's on you because you are the one who has to do the feeding and... the family might try to help and do what they can, but for you, it's emotional. Looking back, for me it's been a happy experience but I can realize how some mothers might just lose it.

(sighs) Yeah...

\section{MARGARET}

\section{ALEX}

I think that becoming a mother has brought our my vulnerable side... because it's so personal and I feel very visible. As a yoga instructor, I have always been confident, present and in tune with my body, as well as my emotions. I am not afraid to show my happiness, or my sadness... I generally tolerate stress pretty well. I have come to a point of mastering things. I have no problem handling feedback professionally but there's something WAY more personal when people comment about you and your child. I am so used to getting reassuring feedback and the positive ones fuel me but today, for the first time, I faced criticism when another mom questioned the way I allowed my son to play. On the surface I took it with calm: sure, that's something that I need to consider but inside it was unlike anything that I've experienced before. It cut really deep, and it felt like peeling back a layer of skin, revealing my veins and muscles. I can't help feeling very visible, and this feels vulnerable.

TAYLOR

Yeah... I think that the whole notion of motherhood has kind of been unreal, the notion of parenthood has been sinking in slowly. It's something that we do, taking care of this little person till the rest of our lives... 
Scene 7: Joy in the relationship

\section{GABRIELA}

Yes, but in the end, it's happiness. It's easy to say that I'm really happy or I love my baby but words really don't begin to describe how I feel. Because there's much more than just happiness, it's a complex kind of happiness.

\section{ALEX}

Yes, definitely. It's a profound, evolving, complex experience and it's mutual. I feel his joy and then my joy as a mom.

\section{GABRIELA}

I would say, for me, in the end, what matters is that the baby thrives, so I would say it's happiness despite adversity.

\section{MARGARET}

I hear that you all really have very personal experiences about becoming a mom, and I'm actually a bit surprised about that. I think that's what's confusing about the whole thing that everyone has a different story...

\section{GABRIELA}

Yes, and everyone tells you what to do...

\section{MARGARET}

Yes, so when you're a new mother, you don't really know...

\section{TAYLOR}

You are right. I'm so glad we are talking about this here.

\section{VICTORIA}

Yes, and I feel that it's important just to hear everyone's perspective so that we can begin to acknowledge that multiplicity of experiences. And begin to be more aware of our own experiences, gain confidence, eventually figure out what works for each of you without fear of judgment. Our time is up for today. The portrait is beginning to take shape, and I would like to add finishing touches to it next time when we meet.

$$
\text { MARGARET, TAYLOR, ALEX, GABRIELA, LIZ }
$$

Ok, great! Thank you! See you next week! (leaving)

\section{VICTORIA}


(Looking at the portrait) Yes, the portrait is really beginning to take shape. The women's stories are inspiring and also bring up memories from the time that I first became a mother.

I related so strongly to Margaret's experiences. I remember that the first post partum weeks had been an emotional turmoil for me, topped with physical and mental exhaustion. I remember it being overwhelming .

I wish I had had an experience like Liz, she seems so content and accepting. I realize that when I first became a mother I must have been much more nervous, anxious and discontent... I see myself in all of the mothers, I can definitely relate to each of them separately and all of them as a group.

END OF ACT II 
SETTING: Artist's studio

AT RISE: Victoria working on the portrait, portrait projected.

(enter Taylor, Alex, Gabriela, Liz, Margaret)

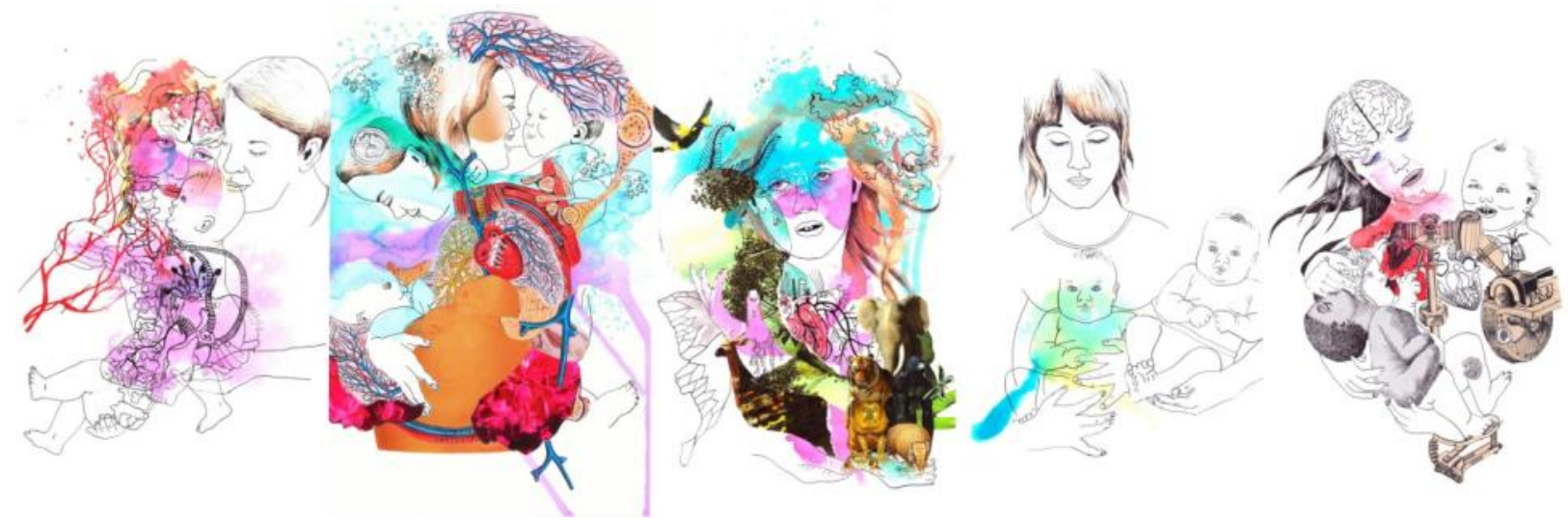

Scene 1: Introduction

TAYLOR, ALEX, GABRIELA, LIZ, MARGARET, VICTORIA:

Hi! Hello! How are you? Good to see you!

VICTORIA

Welcome back! Today is our last meeting and I would like to thank you for all your input and inspiration. It's a living portrait and I've tried to incorporate your presence through your sensations, mood, feelings, and the experiences that you have described. I would like to invite you to devote today's session to imaginal experiences. I wonder if anyone would like to share daydreams, dreams or fantasies about yourself and/or your baby relative to becoming a mother... 


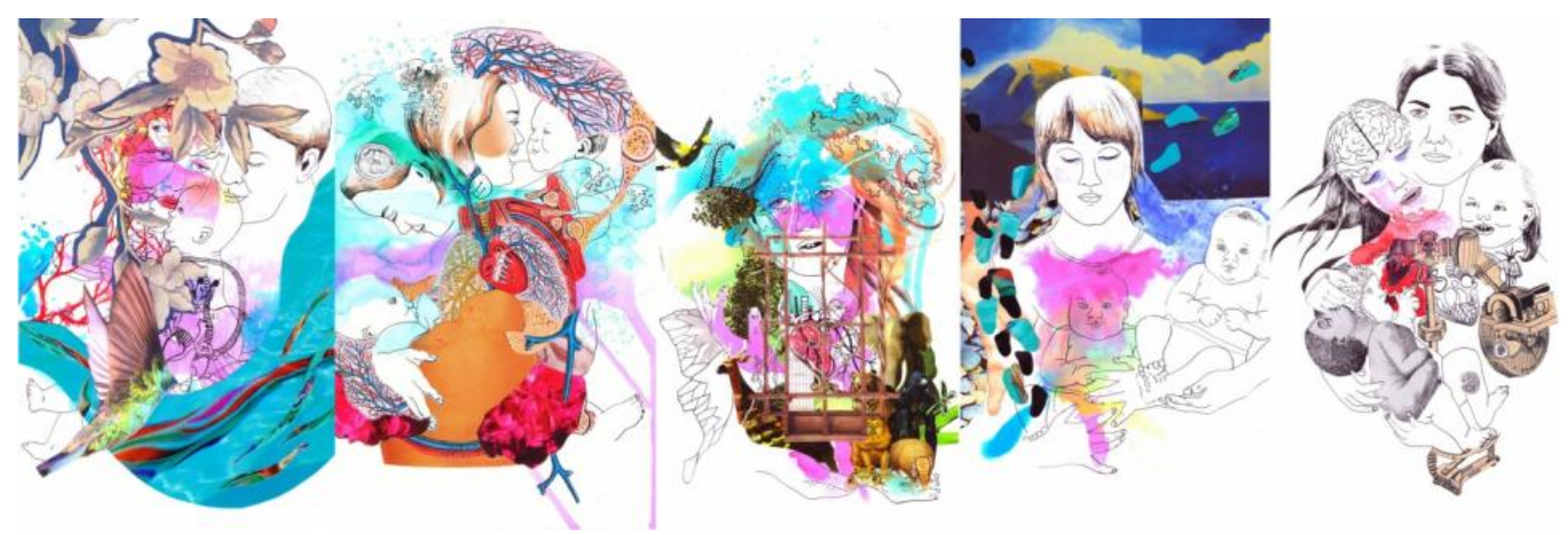

Scene 2: Fantasy of returning to a former life

\section{MARGARET}

I would like to share something that's very present in my life right now. I've been a very independent sort of self-sufficient person. I love exercising, going places. I've gone on road trips by myself, I've moved to places by myself. I was just like a person in the world, taking action. But now I can't do this any more. I feel in pieces: I am leaving my old self behind. I feel compressed as an individual. Again, I am aware that in a way, I am no longer this self-sufficient individual, free to do whatever I want. My body and mind are tied to another human being. It's a big change and I don't fully get a sense yet what is happening. I wonder: Who am I now? What is my role? How did I get here? Like I told you last week, it's like being under water, I feel a little bit like a prisoner, but it's also a beautiful sensation. I am in this beautiful underwater prison.

\section{GABRIELA}

I can totally relate to that! Especially in the beginning, after feeding and feeding endlessly, I was like: I don't have a life. What's going on here? I remember that sometimes after another sleepless night I had this fantasy of opening the door and going back to the life that I had had before becoming a mother: I imagined I could do ANYTHING: go to the gym, go out, go for a run...but I knew that it was not possible. Now that she is sleeping better, things are becoming easier and easier but the beginning was hard.

\section{MARGARET}

Well, it's good to know that it gets better... thank you. This eases my anxiety a bit. 
Yes, but you know, life is never going to be the same again, you can't go back to the life that you had.

TAYLOR

And it's also about the perspective that you choose to take. I, for instance, don't see a change in myself as a person.

MARGARET

I know...,it's all about the perspective. And I'm just trying to put together a new sense of self right now.

Scene 3: Awareness of darker fantasies

ALEX

As I hear you speak, I just want to add that I, too, can relate to your experience, and particularly the early weeks and how confusing and overwhelming it can be. Sometimes I've had dreams that have affected me and that I still remember. Last night I had a dream related to a birth memory but I'm not sure if you would like to hear it...

Of course, go ahead!

TAYLOR, MARGARET, GABRIELA, AND LIZ

ALEX

I haven't told it to a many people because it's so personal and I don't want to be self-centered... And I feel that people really don't have the time or the interest to listen, but I've felt supported in this group and I feel safe to share it with you.

\section{LIZ}

Really, we'd love to hear.

\section{ALEX}

Thank you. Well, the other night I had this visceral, bodily experience. A dream of a flood. A flood of pain, a flood of emotions, a flood of so many new experiences at once. A flood of blood and tissue that came out of me but that manifested in this whole new being. It also brought back the birth and all of the bodily and emotional memories, it was so powerful. It's been 8 months since I give birth and I wonder why these experiences are still coming back in dreams, maybe I'm keeping these emotions inside still?

VICTORIA 
Thanks for sharing this, Alex. I think that it's always a good idea to explore our experiences, even if they seem very personal or frightening, even.

\section{ALEX}

Yes, I definitely think so, I already feel relieved. I just wonder if I'm the only one who's had dreams like that...?

\section{MARGARET}

I'm glad that you talked about that because people usually don't talk much about the more darker fantasies and dreams like that. For myself, I was surprised that becoming a mother brought the more existential questions of life and endlessness and death into my awareness. You start to think about life and death in a little bit of a bigger way... and it really can sometimes feel so terrifying and a little bit depressing and kind of empty. But it also could feel very rich, depending on what's going on. sometimes the night time feels a little bit scary...

\section{TAYLOR}

Wow, Margaret, thanks for sharing that. And Alex, definitely you're not the only one. I've also had dreams and fantasies that I can't explain. Now I remember the dream that I wanted to share with you on the first day! The other night I dreamed that I was still pregnant with Carter. The dream began with a single waterdrop falling inside of me. The waterdrop began in one source and kind of evolved, grew and grew... just emanated from within and became two colorful streams that started emanating and radiating ... until they eventually formed one color that became a fetus. And then, the fetus became a baby. I was holding the baby. And the emanating radiating colors were still there and kept growing, radiating... The whole of notion of motherhood has kind of been kind of unreal... I still don't know what to make of this dream. Carter was born 8 weeks ago but I feel like the connection between us was formed in pregnancy. I was holding him and caring about him even before he was born, and now this connection continues to emanate, to radiate, to grow.

Scene 4: Positive fantasies for the future

GABRIELA

Which make me think of a fantasy that I have, that her life is going to be the best thing ever...and really that's a fantasy because you don't know... 
Yes, me, too! I have visions of him getting older, playing in the park on the swings... being really smart at school. And as a person, the personality that he'll develop. And how much that might be like his dad or I. That's kind of interesting.

\section{LIZ}

I also look forward to when he can go outside and play in the park and notice the flowers, and play with caterpillars and bugs and water... and I'd like to weave a gorgeous wrap that's made out of everything beautiful in the entire world and drape him in it.

TAYLOR

But then again, It's been only 8 weeks but I already have visions of him getting older... and how our relationship has evolved and a how it is going to evolve even more. And I wonder if I'm trying to already figure it all out for him. I want to let him explore, not to be too controlling. I imagine us starting out on a path: there are two pairs of footprints on the path that path initially walk side by side......and then begin to diverge. Eventually, Carter will find his own path, and I will stay on mine.

And I imagine that even though eventually he will find his own path, the connection that began when I was pregnant with him will continue until the rest of our lives.

\section{VICTORIA}

Thank you all for your presence and sharing. This has been really inpsirational. Our time is up today but next week, I'll show the finished portrait to you and you can provide feedback.

GABRIELA, TAYLOR, ALEX, LIZ, MARGARET

Yes! Great! Thank you! see you next week

$$
\text { (all exit) }
$$

END OF ACT III

AT RISE 


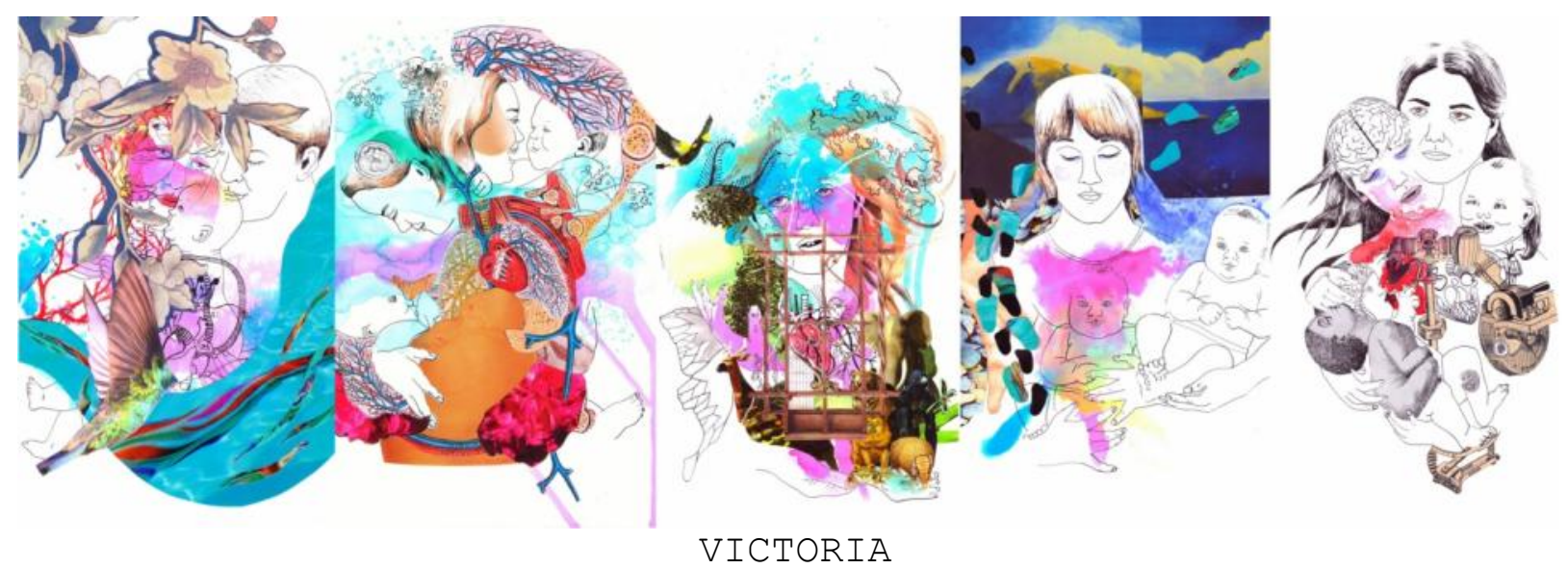

The 5 moms have sat for the group portrait in three sessions. I have been working on the portrait for several weeks now, trying to capture their experiences. The portrait is finished and the sitters will be here any minute to take a look at it and give me feedback about the portrait. I'm really curious to hear their opinions but also a bit nervous. For me, this montage portrait captures a variety of experiences. I tried to convey their experiences as they spoke, so I kept adding to and layering the portrait. It was important for me to portray their inner lives, and to convey the richness of their experience, using the similes and metaphors that they came up with. I am also aware that it may be difficult for some moms to face their portraits. They were very open and honest about their experiences, and I included all of the themes and categories that emerged, both joyful and challenging. Moreover, this portrait is really a cocreation because it was born through my interaction with the sitters. I used what they conveyed to me, but also my own impressions and observations to create the portrait. I believe that this multiplicity enriches the portrait, and shows the sitters as evolving, living people with a variety of emotions and experiences.

(knock on he door)

Oh, here they are!

VICTORIA

(opens the door)

VICTORIA

Hi! How are you? Good to see you again.

Hi! Hello!

LIZ, GABRIELA, MARGARET, ALEX, TAYLOR 
VICTORIA

Come on in, take a seat. First of all, thank you so much for taking the time to sit for this portrait. I know that you all have busy lives and you are all in your first year of motherhood, and this is a big transition. I really appreciate your time, thoughtfulness and contribution. I am so inspired by all of you and your experiences. The portrait is now ready for your viewing and feedback.

(portrait being projected on the screen)

So, what do you think?

VICTORIA

ALEX

Wow, I'm so excited and touched.

\section{MARGARET}

I like the complexity and vibrancy and plural feeling.

TAYLOR

I feel a sense of pride, warmth, happiness, contentment...because I'm still on the same emotional path.

I feel warmth and love.

\section{GABRIELA}

I think it's a great graphic representation of my transition to motherhood, I like the way it evolves and shows both the challenges and rewards.

\section{MARGARET}

I agree, the most fascinating aspect of this portrait's representation of motherhood is seeing its progress, the constant unfolding of the experience. I would say that the unfolding of an artwork seems like an accurate way to represent the unfolding of the experience itself.

TAYLOR

I also strongly relate to the evolving aspect of it. It's all a journey and it takes time to walk the path, and every day is different, presented with new challenges.

\section{MARGARET}

And it can be quite complex... 
LIZ

...and chaotic even. I guess I found it hard to express but now I see it in the artwork.

\section{VICTORIA}

I wonder, what are your emotional reactions to seeing the portrait?

\section{GABRIELA}

I had an emotional response. After a year, the difficulties of breastfeeding and the marathon feeding sessions had been deeply stored away in some corner of my brain however the portrait reminded me of how painful and stressful this time was. The portrait however also made me re-experience the transition out of these hard times to calmer and happier times.

\section{MARGARET}

I feel a little bit of self-pity and also some self-love. I would like to thank you all for sharing your experiences with me. I felt supported in my journey and realized I'm not the only one in this transition. I want to tell myself that it will get better in just a short time and give myself a reassuring hug.

TAYLOR

I also feel reassured. I try not to get too overwhelmed, I pace myself, and I have this omnipresent feeling of love for this tiny human being. I never knew such a feeling could exist, but I'm constantly reminded of how amazing it is that he's here and in my life, affecting it every moment. The portrait reminds me of those feelings, and the journey we're on together, and how excited I am to help him on his path through life and see where that will take him.

\section{ALEX}

I also have an emotional response to all the pictures as a whole set. I was struck at the progress we made through the process. It also evokes even more love for my son. In seeing the synthesis, initially I was very excited and touched. It allows me permission to offer myself loving kindness.

VICTORIA

Thank you for sharing these thoughts. I also wonder, was participation in this project useful for you in any way? 
GABRIELA

Yes, it was useful to me in the sense that it gave me an opportunity to reflect on the immense effort that is motherhood and to appreciate the process despite its hardship.

TAYLOR

Yes, I agree, reflection on my emerging relationship with my son was really useful.

\section{ALEX}

Speaking of which, I must say that describing my experience to supportive, non-judgmental people was very useful. It felt good to tell my story. Thank you all!

\section{GABRIELA}

And it's hard to express what it feels like to become a mother, in using just words. So I think the artistic representation shows the experience.

\section{LIZ}

I agree. For me, seeing the artistic representation of the metaphor of weaving something beautiful to wrap around my baby was very powerful.

\section{MARGARET}

I think that it was a useful way to think through what I was feeling, discover the feelings and the artwork gives form to these feelings. It seems like when you draw something and turn it into something physical it doesn't feel as threatening or scary. It just is what it is. So perhaps I gained some acceptance in this exercise.

VICTORIA

Do you think this project could be useful for others such as new mothers and mothers-to-be?

LIZ

As others pointed out, the reflective aspect stand out really strongly for me. I would highly recommend to new mothers to take 
some time and reflect on their experience. For me, it was useful.

\section{GABRIELA}

Yes, and I hope that in doing so, they realize that becoming a mother is not all a great happy experience all the time, and it's ok. Nobody told me about the difficulties that lay ahead and the relationship with a newborn, at least in my experience, is far from blissful. It was great to talk to other moms in this group and I hope that other new moms might also see that it is okay to experience feelings as they come in the transition to motherhood, even if those do not seem fitting of a mother.

TAYLOR

I think it's helpful to hear the whole story from new mothers to mothers-to-be, and anyone really. There's a lot of horror and war stories people like to tell, but sometimes the good moments get overlooked, so it's good to share the whole story, because one woman's experience might differ vastly from the next woman. I think the primal nature of motherhood is still wildly underrepresented and misunderstood, so the more information about that out there for the public to discern, the better. And then maybe it will lead to better support for new moms across all spectrums.

\section{ALEX}

But then again, although we have all have presented our stories, in the end, every birth, every mother-child dyad, is the same.

\section{VICTORIA}

Thank you for all of this feedback. Finally, to conclude, what was it like for you to participate in this project?

GABRIELA

I think it was really a time to reflect on transitioning to motherhood. It all happens so fast from the time you deliver to now, which now is like 11 months, it's non-stop. You go from delivering and now you have to feed this baby, you didn't sleep at all, you have to keep going. So it's been a time to reflect and think: wow, you know that was hard, and I'm glad it's done, and now we're in a different phase...

LIZ

I agree. For me, it's been clarifying, I guess, is some ways. I haven't actually been reflecting like this. I've just been 
taking care of the baby. So it's nice to pause and think about my experiences.

TAYLOR

Yes! To think little bit broader than the day to day (laughs) like eating, sleeping, pooping. It was nice to do something for him but for me at the same time. To be able to sit down and have some passive time and not do anything. It was nice, kind of like introscpection, I think. But it was also interactive.

\section{ALEX}

Yeah, it was LOVELY. It's so nice to get a moment to focus on my own experiences.

I feel like that there's so much attention to prep and primacy. And mom gets a lot of attention to care for the unborn child. And then rightfully so, and understandably so, attention is given to the child. And I wanted it to be so. When I became a mom, I didn't want attention for me but I wanted attention to self-reflect. So that's what I experienced by participating in this project.

And umm just take a moment to... yeah, create some metaphors. Not just talk about it but metaphors allow me to get closer to the embodied experiences that's so... I think... the metaphor is what allows the experience of beyond words to be relived.

To conclude, I'm feeling sentimental but also just nourished. A little more embraced and ... a little fueled in a positive way.

MARGARET

For me, it was liberating. I'm really glad that I did this, I'm so glad I participated. 